\title{
Effect of Heat Input Variations to the Mechanical Properties and Pitting Corrosion in the Dissimilar Stainless-Steel Welding
}

\author{
Sutrimo $^{1}$ Ating Sudradjat ${ }^{1}$ Rayhan Nugraha $^{1}$ Fachri Koeshardono $^{1}$ Aris $\operatorname{Suryadi}^{1} \operatorname{Deni}_{\text {Mulyana }}{ }^{1}$ and \\ Ita Casmita ${ }^{1}$ \\ Research Scholar ${ }^{1}$ \\ ${ }^{1}$ Department of Mechanical Engineering \\ Bandung State Polytechnic, \\ Bandung Barat, West Java \\ Indonesia
}

\begin{abstract}
Advancement in the manufacturing of the mechanical product is required to meet the demand. The consumer needs the product to have more functions and also lighter. One key aspect of product manufacturing is the joining of material for parts. The Welding is one type of joining method and mostly used for metal joining. The new challenge in welding is fusing two different ones. The study in this paper is a starting point for research, especially in developed countries about the dissimilar metal joint. The Welding process that investigated is Gas-Tungsten Arc Welding. Base materials are two different types of stainless steel (AISI 304L and AISI 316L). They have different melting points, so the keys in this process are metal filler and heat input. Metal filler which is stainless steel class ER 308 (per standard ISO) is used as the control variable. Independent variable in this study is heat input which contains electrical voltage (fixed) and electrical current (changed). There are two dependent variables as observation points: mechanical properties of material (strength and hardness) and pitting corrosion. In conclusion, the study could be used as a guide for future research in the welding of metals. The optimum parameter is $0.807 \mathrm{~kJ} / \mathrm{min}$.
\end{abstract}

Key Words: Dissimilar Metal Joint, Gas-Tungsten Arc Welding, Mechanical Properties of Material, Pitting Corrosion, Welding Parameter.

\section{INTRODUCTION}

Advancement in manufacturing of mechanical product is required in order to meet the demand. The consumer needs the product to have more functions and also lighter. One key aspect in the product manufacturing is the joining of material for parts. Welding is one type of joining method and mostly used for metal joining. The new challenge in welding is fusing two different ones. The research in this topic has been conducted for several years. The type of materials that is joined in those researches could be classified into: ferrous to non-ferrous [1], two different steel classes [2], two different aluminum class [3-5], steel with copper [6 27], steel with aluminum [28-32], steel with nickel [33], steel with titanium [34, 35], aluminum with copper [36- 41], aluminum with titanium [42, 43] and super alloys [44]. The methods of dissimilar metal joining method are several of them including: GasTungsten Arc Welding [9], Shielded Metal Arc Welding [12, 13], Friction Welding [3, 4, 10, 28, 29, 31, 32, 36-41], Electron Beam Welding [14, 18, 23, 24, 27] and Laser Welding [2, 5, 6, 11, 16, 17, 19-21, 22, 26, 30, 33, 34, 35, 42, 43, 44, 45]. From those two points of interest, it could be inferred that steel-copper welding and laser welding have the most widely studied in the world of dissimilar metal joint especially by welding.

This paper, however, discusses the dissimilar metal joint of two different stainless steel. There are some debates about the degree of dissimilarity that the joint could be classified as the dissimilar metal joint. As explained in G. R Mohammed [2], the subjects of the study in this paper could be justified even though using a different method of welding. Gas-Tungsten Arc Welding (GTAW) still widely used in the industry, so the topic itself still relevant. So, there are 3 materials to be considered: first base metal, second base metal, and metal filler. The distinct problem in the dissimilar metal joint is the galvanic corrosion because of differences in electrode potential. The corrosion itself has specific shapes similar to pit so, it is called pitting corrosion. So, in conclusion, the quality of the welding process of two different stainless steel has to be tested by its mechanical properties (strength and hardness) and also its corrosion resistance. 


\section{METHOD}

The method of research could be explained in this sequence: specimen preparation per standard AWS D1.6, the welding process (GTAW) and the test (mechanical properties and corrosion resistance).

\subsection{Specimen Preparation}
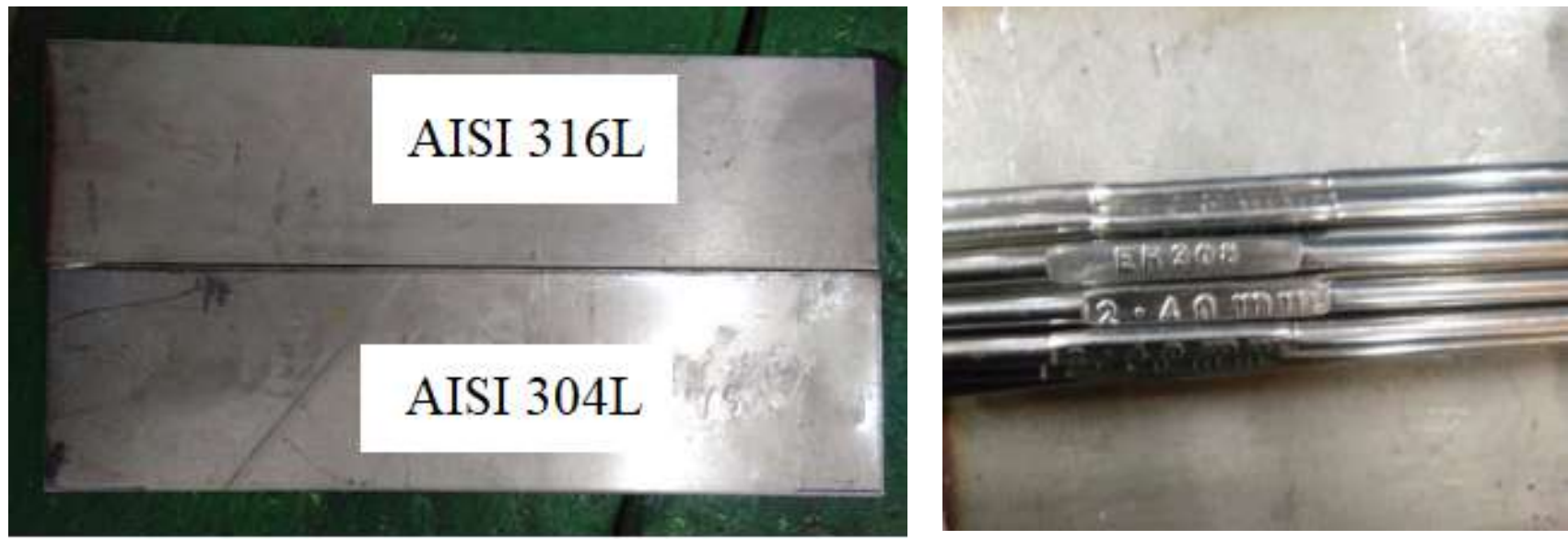

Figure1. Base metals and metal filler

The process of preparation is by cutting the plate with $3 \mathrm{~mm}$ in thickness into the size of $250 \mathrm{~mm}$ by $125 \mathrm{~mm}$. This size is according to AWS D1.6. Make 3 for each specimen. Also, in this process, the metal filler must be prepared. In this study, ER 308 is used with $2,4 \mathrm{~mm}$ in diameter.

\subsection{Welding Process}

Table1. Welding parameter in the experiment

\begin{tabular}{|c|c|c|c|c|c|c|c|c|}
\hline $\begin{array}{c}\text { Current } \\
(\mathbf{A})\end{array}$ & $\begin{array}{c}\text { Voltage } \\
(\mathbf{v})\end{array}$ & $\begin{array}{c}\text { Welding } \\
\text { speed } \\
(\mathbf{m m} / \mathbf{m})\end{array}$ & $\begin{array}{c}\text { Shielding } \\
\text { Gas }\end{array}$ & $\begin{array}{c}\text { Argon } \\
\mathbf{f l o w} \text { rate } \\
(\mathbf{L} / \mathbf{m i n})\end{array}$ & $\begin{array}{c}\varnothing \text { Filler } \\
(\mathbf{m m})\end{array}$ & $\begin{array}{c}\varnothing \text { Tungsten } \\
(\mathbf{m m})\end{array}$ & $\begin{array}{c}\text { Heat Input } \\
(\mathbf{k J} / \mathbf{m m})\end{array}$ & Polarity \\
\hline 85 & 14 & 73.53 & $99 \% \mathrm{Ar}$ & 10 & 2.4 & 2.4 & 0.971 & DCRP \\
\hline 75 & 14 & 69.44 & $99 \% \mathrm{Ar}$ & 10 & 2.4 & 2.4 & 0.907 & DCRP \\
\hline 65 & 14 & 65.79 & $99 \% \mathrm{Ar}$ & 10 & 2.4 & 2.4 & 0.830 & DCRP \\
\hline
\end{tabular}

A welding process in the study is conducted in Table 1. From the table, it could be seen that the variable changed is the current. The variations are from $85 \mathrm{~A}$ to $65 \mathrm{~A}$. Welding speed is also adjusted according to previous experience, so it has also changed to maintain the quality of weldment. However, the main focus of this study still the electrical current.


Figure2. GTAW machine and the shielding gas tank

The pieces of equipment and the tools that have to be prepared are as followed: 
International Journal of Advances in Scientific Research and Engineering (ijasre), Vol 5 (10), October-2019

1. GTAW machine

2. Filler ER NiCr-3 Ø $2.4 \mathrm{~mm}$.

3. Electrode $\varnothing 2.4 \mathrm{~mm}$.

4. Shielding gas High Purity (HP) Argon

5. Gloves

6. Automatic welding helmet

7. Apron

8. Plier

9. Steel wire brush

10. Chipping Hammer

11. Hand grinding machine

12. Ear Plug
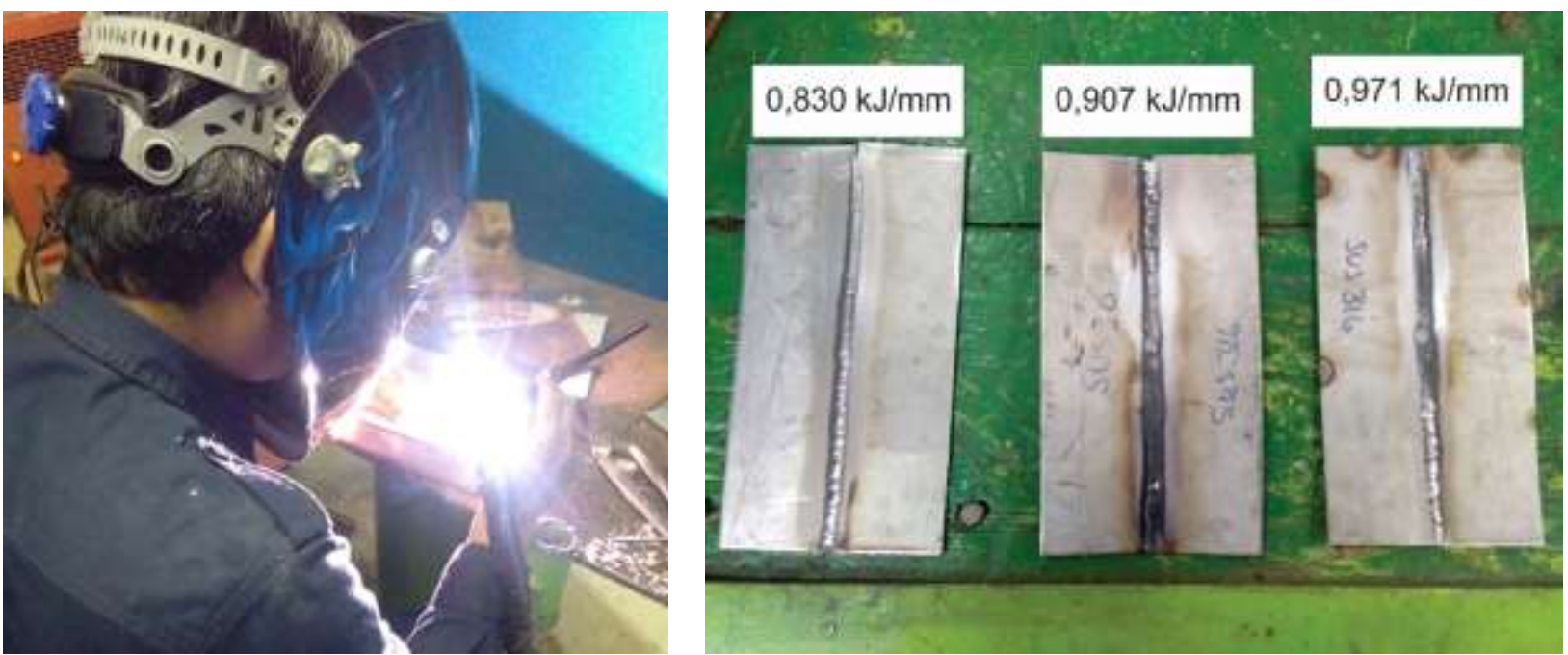

Figure3. Welding process and its results

The process of welding is worked by the certified welder. The skill of welder would not be the source of error in this study.

\subsection{Mechanical Properties Test}

There are two types of test to determine its mechanical properties: strength by tension test and hardness by hardness test.

\subsubsection{Tension test}

The first step to conduct the tensile test is by making the test specimen. The specification of the specimen is regulated in ASTM E8.
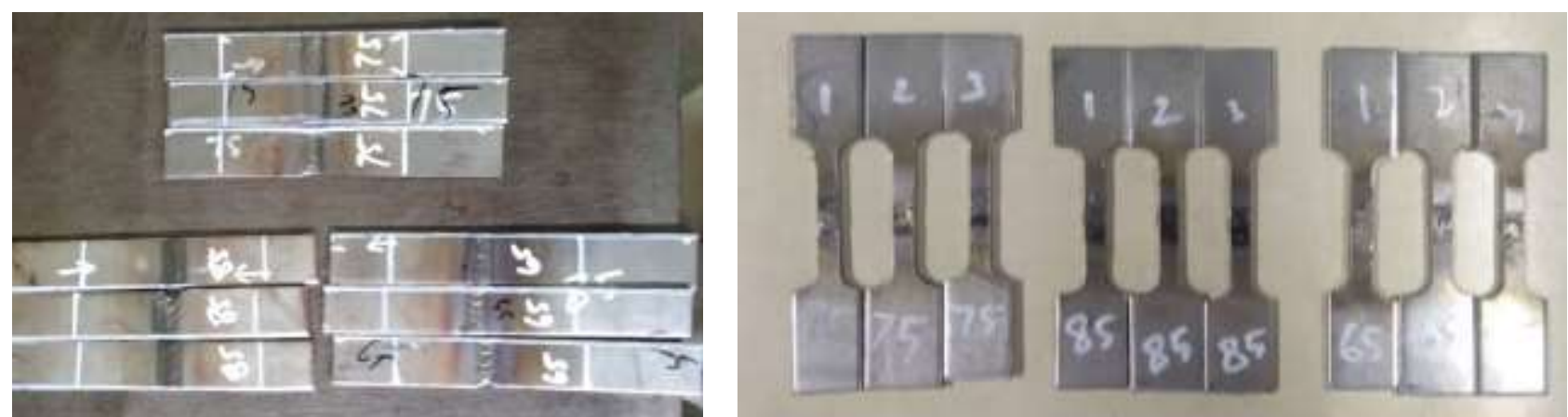

Figure3. Tensile test piece before and after cut according to ASTM E8 
International Journal of Advances in Scientific Research and Engineering (ijasre), Vol 5 (10), October-2019
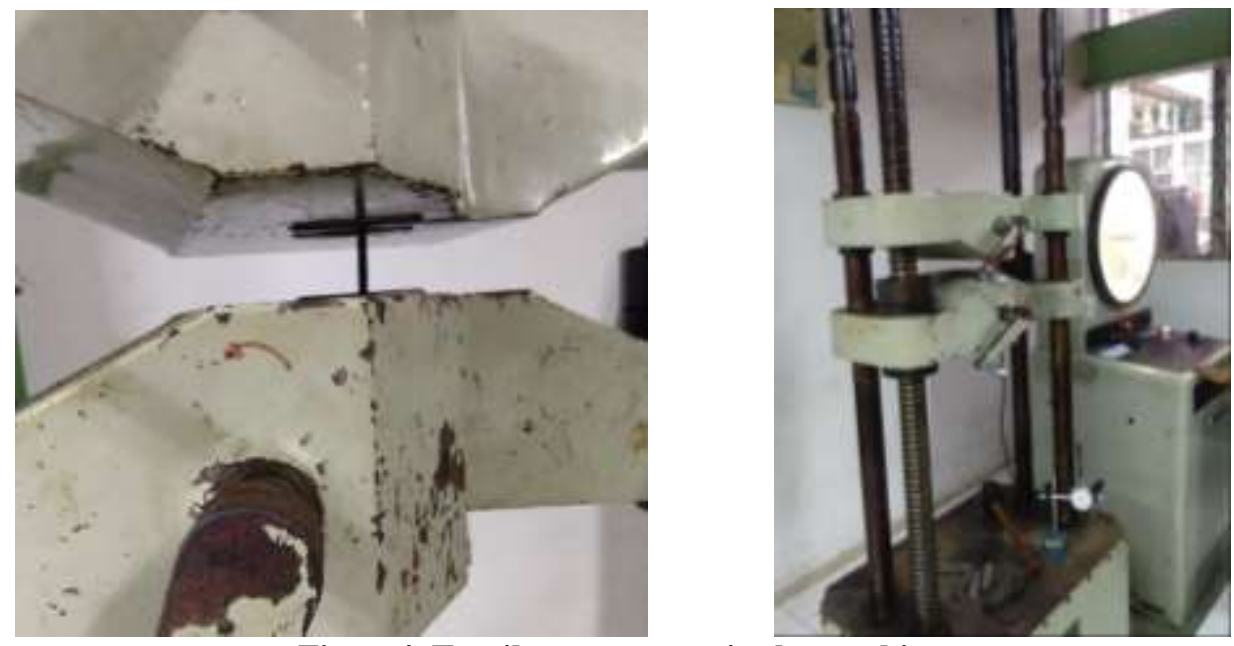

Figure4. Tensile test process in the machine

After that, 3 test pieces for each heat input (Figure 3) then tested. So, in total, there are 9 tests.

\subsubsection{Hardness test}

There are several zones for hardness test: heat-affected zone (HAZ), weld metal, fusion line, dan base metal. The tests are according to ASTM E384 (Standard Test Method for Microindentation Hardness of Materials). The test machine Digital MicroHardness Tester by hardness Vickers (HV) number.

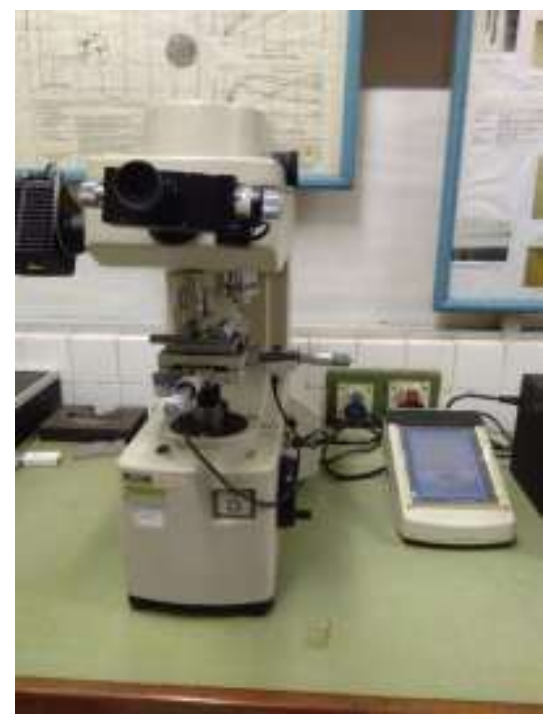

Figure5. Hardness test process in the machine

\subsection{Corrosion Test}

The first step to conduct the corrosion test is by making the test specimen. The specification of the specimen is regulated in ASTM G48.
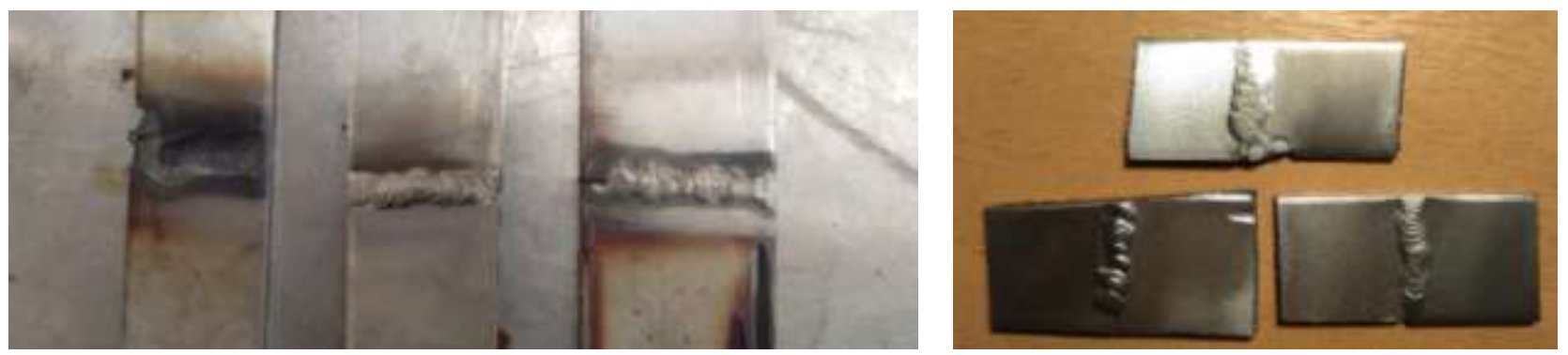

Figure6. Corrosion test piece before and after polishing 

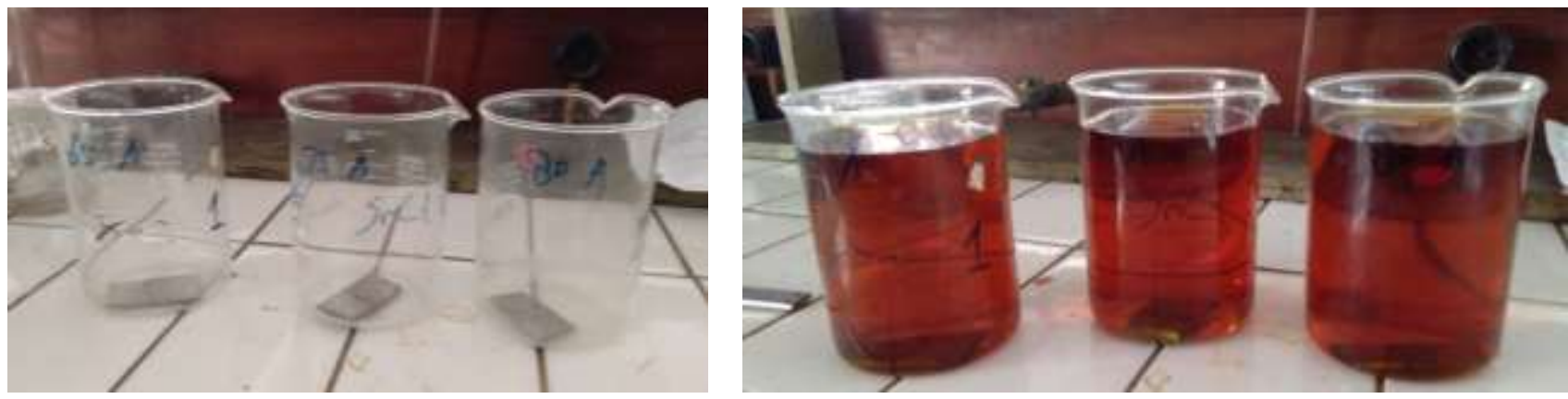

Figure7. Corrosion test piece before and after dipped into the solution.
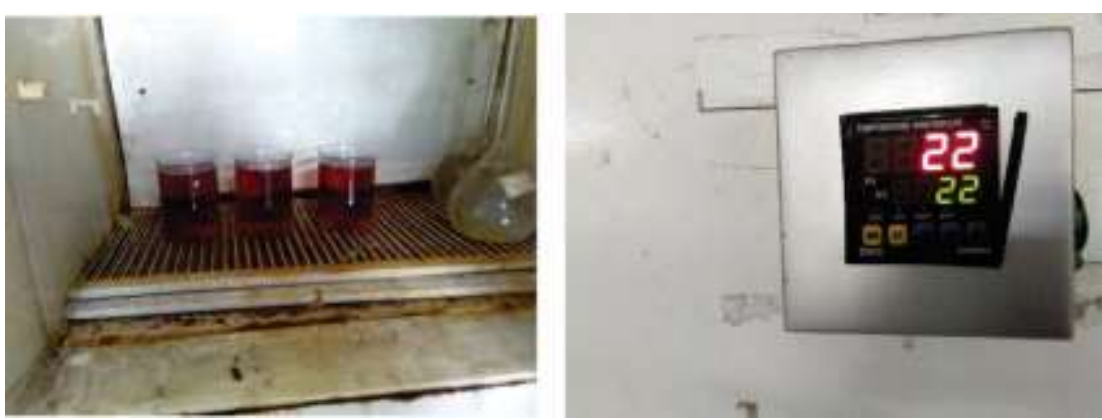

Figure8. Incubation process

After that, each specimen is weighed and noted. Then, each test piece is dipped into $600 \mathrm{ml} \mathrm{FeCl3} \mathrm{6 \%} \mathrm{solution} \mathrm{(Figure} \mathrm{7).} \mathrm{Then}$ all of them is incubated by controlling the temperature to $22^{\circ} \mathrm{C}$ for 72 hours (Figure 8).

\section{RESULT AND DISCUSSION}

There are 3 results according to previous tests: strength, hardness, and corrosion.

\subsection{Tensile and yield strength}

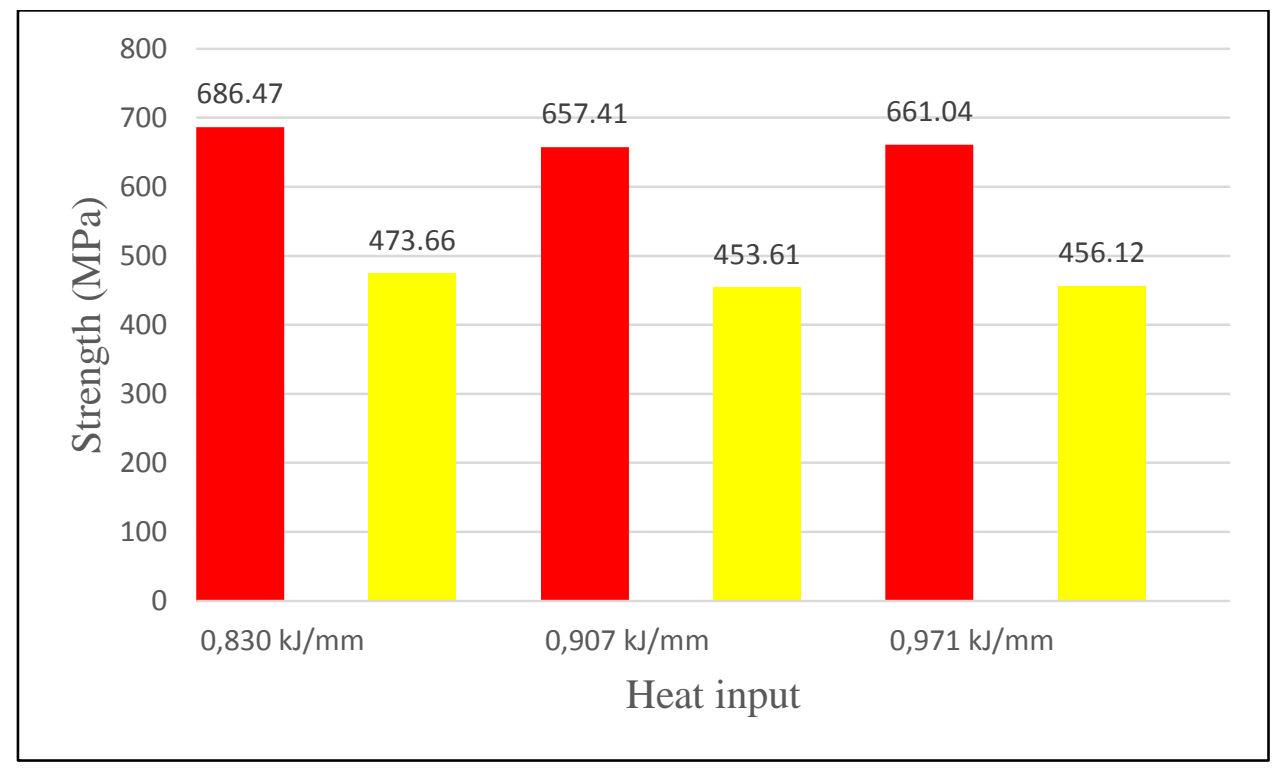

Figure9. Tensile (red) and yield (yellow) strength results

Based on the results in the graph, the highest tensile test is when the heat input $0,830 \mathrm{~kJ} / \mathrm{mm}$ because with this value give the low penetration. It also concluded that the higher the heat input, the tensile strength is getting lower. The high value of heat input also means a higher rate of cooling. The result is that the grain is getting bigger, so the tensile strength is low. It is fit with the HallPetch Equation.

\subsection{Hardness}

The test is conducted to determine hardness value for every zone in the weldment. There are 30 points in base metal (BM), heat affected zone (HAZ), and weld metal (WM) with space every $0,25 \mathrm{~mm}$. 


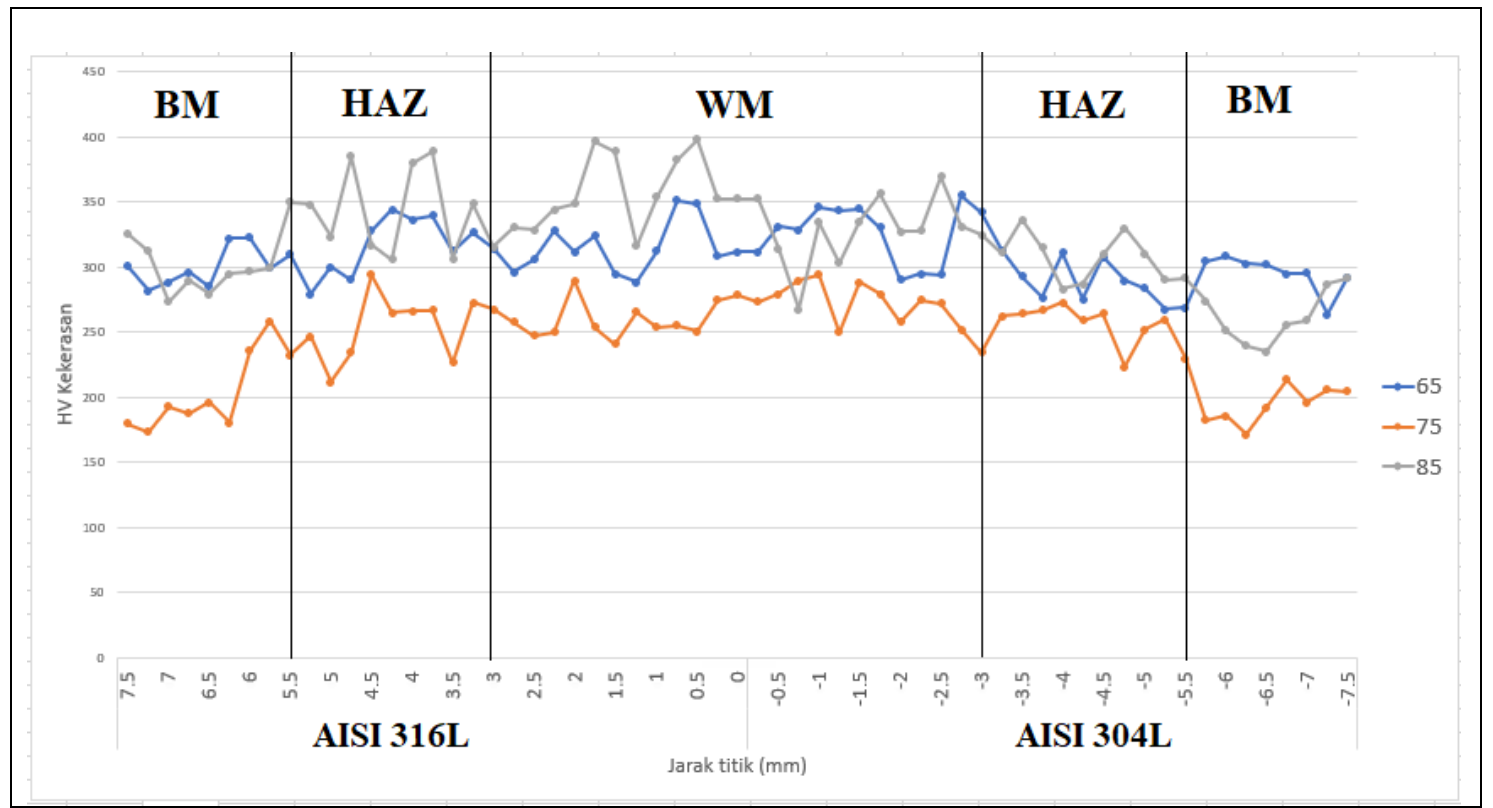

Figure10. Hardness value graph

The graph shows that in the area of WM, hardness is higher than those in HAZ and BM. It is also to be noted that AISI 316L HAZ is harder than at AISI 304L. Different from the strength test, the lowest value of hardness occurs when heat input is $0,907 \mathrm{~kJ} / \mathrm{mm}$.

\subsection{Corrosion}

Corrosion test purpose is to determine the corrosion resistance in the joint by applying $\mathrm{FeCl}_{3}$. It could be concluded that differentiation in electrical current affecting the resistance to corrosion in the dissimilar metal joint.

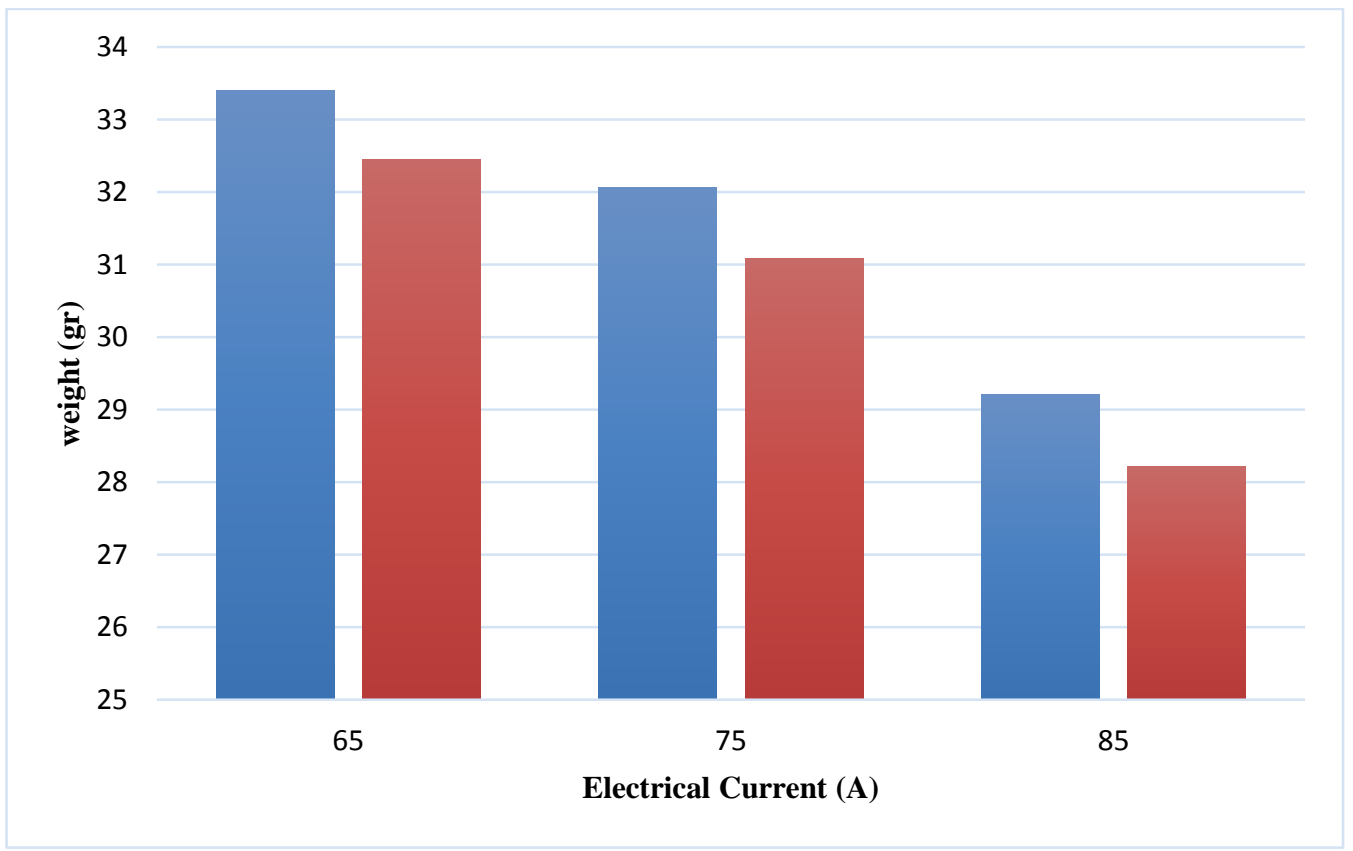

Figure11. Weight of specimen before (blue) and after (yellow) the test

From the observation under a microscope, there are some differences in corrosion resistance for every heat input. It is to be noted that when the heat input 0.971 , pitting corrosion occurs at AISI 304L in HAZ area. However, in AISI 316L the corrosion occurs in the base metal. At heat input 0.907, AISI 304L corroded at the area of HAZ and fusion line. Hence, no corrosion in HAZ of AISI $316 \mathrm{~L}$. 


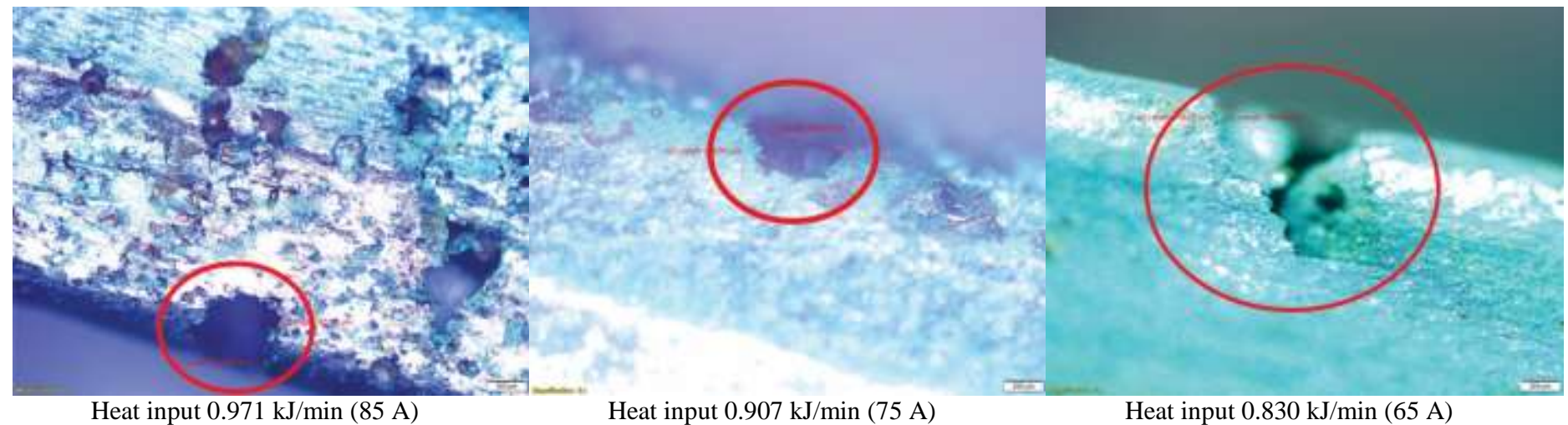

Figure12. Observation under the microscope by magnifying 20 times

When heat input 0.830 , there is erosion in the weld metal. However, there are some holes caused by pitting corrosion AISI 304L at HAZ and base metal.

\section{CONCLUSION}

From the study, it could be concluded that:

1. Heat input variations in GTAW for dissimilar metal joint has a significant impact on its mechanical properties and also corrosion resistance

2. The optimum heat input for the process is $0.830 \mathrm{~kJ} / \mathrm{min}$

\section{ACKNOWLEDGMENT}

Authors express its gratitude to Politeknik Negeri Bandung from giving every support in this research. Authors wishing to acknowledge assistance or encouragement from the people from MIDC (Metal Industries Development Center) in analyzing the corrosion that is provided for the case in this paper.

\section{REFERENCES}

1. G. Thirunavukarasu et al,"Scope for Improved Properties of Dissimilar Joints of Ferrous and Non-Ferrous Metals", Transactions of Nonferrous Metals Society of China, vol.27, Issue 7, pp.1517-1529, 2017.

2. G.R Mohammed et al,"Fiber Laser Welding of Dissimilar 2205/304 Stainless Steel Plates”, Metals, vol.7, pp.546, 2017.

3. P.B. Srinivasan et al,"Stress Corrosion Cracking Susceptibility of Friction Stir Welded AA7075-AA6056 Dissimilar Joint", Materials Science and Engineering: A, vol.392, Issues 1-2, 2005.

4. P. Cavaliere et al, "Effect of Welding Parameters on Mechanical and Microstructural Properties of Dissimilar AA6082AA2024 Joints Produced by Friction Stir Welding”, vol.30, Issue 3, pp.609-616, 2009.

5. A. Orishich et al,"Analysis of the Effect of the Thermomechanical Processing on the Laser Weld Joint of Aluminum Alloys of Al-Mg-Li and Al-Cu-Li", Procedia CIRP, vol.74, pp.442-445, 2018.

6. C. Yao et al, "Interface Microstructure and Mechanical Properties of Laser Welding Copper-Steel Dissimilar Joint", Optics and Lasers in Engineering, vol.47, Issue 7-8, pp.807-814, 2009.

7. S.D. Kore et al, "Application of Electromagnetic Impact Technique for Welding Copper-to-Stainless Steel Sheets", International Journal Manufacturing Technology, vol.54, pp.949-955, 2011.

8. J-T. Xiong et al,"Diffusion Bonding of Stainless Steel to Copper with Tin Bronze and Gold Interlayers”, Journal of Materials Engineering and Performance, vol.21, issue 1, pp.33-37, 2012.

9. S.G Shiri et al, "Gas Tungsten Arc Welding of CP-Copper to 304 Stainless Steel Using Different Filler Materials", Transactions of Nonferrous Metals Society of China, vol.22, Issue 12, pp. 2937-2942, 2012.

10. J. Luo et al,'Radial Friction Welding Interface Between Brass and High Carbon Steel”, Journal of Materials Processing Technology, vol.212, Issue 2, pp.385-392, 2012.

11. S. Chen et al,"Microstructural Characteristics of a Stainless Steel/Copper Dissimilar Joint Made by Laser Welding", Metallurgical and Materials Transactions A, vol.44, Issue 8, pp.3690-3696, 2013.

12. M. Velu and S. Bhat,"Metallurgical and Mechanical Examinations of Steel-Copper Joints Arc Welded Using Bronze and Nickel-Base Superalloy Filler Materials", Materials \& Design, vol.47, pp.793-809, 2013.

13. C. Roy et al, "Characterization of Metallurgical and Mechanical Properties of Commercially Pure Copper and AISI 304 Dissimilar Weldments," Procedia Materials Science, vol. 5, pp. 2503-2512, 2014.

14. B-G. Zhang et al,'Electron Beam Welding of 304 Stainless Steel to QCr0.8 Copper Alloy with Copper Filler Wire", Transactions of Nonferrous Metals Society of China, vol.24, Issue 12, pp.4059-4066, 2014.

15. G. Turichin et al, "Effect of Peculiarities of Heat Transfer, Diffusion and Phase Transformation on Joint Formation During Welding of Dissimilar Materials by High Power Fiber Laser,” Physics Procedia, vol. 56, pp. 566-575, 2014.

16. G.A. Turichin et al,"Effect of Thermal and Diffusion Processes on Formation of the Structure of Weld Metal in Laser Welding of Dissimilar Materials", Metal Science and Heat Treatment, vol.55, issue 9-10, pp 569-574, 2014.

17. V.B. Shaibu et al,'Computational Modeling of Dissimilar Metal CO2 Laser Welding: Applied to Copper and 304 Stainless Steel”, Procedia Engineering, vol.127, pp.208-214, 2015. 
18. B-G Zhang et al, "Effects of Filler Wire on Residual Stress in Electron Beam Welded QCr0.8 Copper Alloy to 304 Stainless Steel Joints", Applied Thermal Engineering, vol.80, pp.261-268, 2015.

19. T. Suga et al,'Laser Brazing of a Dissimilar Joint of Austenitic Stainless Steel and Pure Copper”, Welding International, vol 30, pp.166-174, 2015.

20. S. Chen et al, "Influence of Processing Parameters on the Characteristics of Stainless Steel/Copper Laser Welding", Journal of Materials Processing Technology, vol.222, pp.43-51, 2015.

21. Y. Li et al,'Microstructures and Mechanical Properties of H62 Brass-316L Stainless Steel in Overlap Welded Joints by Continuous-Wave Laser", International Journal Advance Manufacturing Technology, vol.79, pp.627-634, 2015.

22. B.R. Moharana et al, "Experimental Investigation on Mechanical and Microstructural Properties of AISI 304 to Cu Joints by $\mathrm{CO}_{2}$ Laser”, Engineering Science and Technology, an International Journal, vol.19, pp.684-690, 2016.

23. S. Guo et al, "Effect of Beam Offset on the Characteristics of Copper/304 Stainless Steel Electron Beam Welding", Vacuum, vol.128, pp. 205-212, 2016.

24. J. Kar et al,'Effect of Beam Oscillation on Electron Beam Welding of Copper with AISI-304 Stainless Steel”, Journal of Materials Processing Technology, vol.233, pp.174-185, 2016.

25. T.Soysal et al,"Macrosegregation in Dissimilar-Metal Fusion Welding”, Acta Materialia, vol.110, pp.149-160, 2016.

26. S.V. Kuryntsev et al, "Fiber Laser Welding of Austenitic Steel and Commercially Pure Copper Butt Joint", Optics and Lasers in Engineering, vol.90, pp.101-109, 2017.

27. J. Kar et al,'X-Ray Tomography Study on Porosity in Electron Beam Welded Dissimilar Copper-304SS Joints", Vacuum, vol.149, pp.200-206, 2018.

28. H. Uzun et al, "Friction Stir Welding of Dissimilar Al 6013-T4 to X5CrNi18-10 Stainless Steel", Materials \& Design, vol.26, Issue 1, pp. 41-46, 2005.

29. T. Tanaka et al, "Comprehensive Analysis of Joint Strength for Dissimilar Friction Stir Welds of Mild Steel to Aluminum Alloys", Scripta Materialia, vol.61, issue 7, pp.756-759, 2009.

30. Y. Kawahito et al,"Study of Dissimilar Metal Joint for Low Carbon Steel and Aluminum Alloy with Laser-Assisted Metal and Plastic Direct Joining", Quarterly Journal of the Japan Welding Society, vol.30, Issue 2, pp.142-148, 2012.

31. Z. Shen et al, "Role of Welding Parameters on Interfacial Bonding in Dissimilar Steel/Aluminum Friction Stir Welds.", Engineering Science an International Journal, vol. 18, pp.270-277, 2015.

32. T. Kakiuchi et al, "Evaluation of Fatigue Crack Propagation in Dissimilar Al/Steel Friction Stir Welds", Material \& Design, vol.90, pp.669-681, 2016.

33. Y. Hu et al, "Heat and Mass Transfer in Laser Dissimilar Welding Stainless Steel and Nickel”, Applied Surface Science, vol.258, Issue 15, pp.5914-5922, 2012.

34. Y. Zhang et al,"Nd:YAG Pulsed Laser Welding of Dissimilar Metals of Titanium Alloy to Stainless Steel", The International Journal of Advanced Manufacturing Technology, vol.94, Issue 1-4, pp. 1073-1085, 2017.

35. J. Ning et al,'Narrow Gap Multi-Pass Laser Butt Welding of Explosion Welded CP-Ti/Q235B Bimetallic Sheet by Using a Copper Interlayer", Journal of Alloy and Compounds, vol.701, pp.587-602, 2017.

36. T. Saeid et al,'Weldability and Mechanical Properties of Dissimilar Aluminum-Copper Lap Joints Made by Friction Stir Welding", Journal of Alloys and Compounds, vol.490, Issues 1-2, pp.652-655, 2010.

37. P. Xue et al,"Enhanced Mechanical Properties of Friction Stir Welded Dissimilar Al-Cu Joint by Intermetallic Compounds", Materials Science and Engineering: A, vol.527, Issues 21-22, pp. 5723-5727, 2010.

38. F. Ji et al,"Microstructure and Properties of $\mathrm{Cu} / \mathrm{Al}$ Joints Brazed with Zn-Al Filler Metals", Transactions of Nonferrous Metals Society of China, vol.22, Issue 2, pp.281-287, 2012.

39. $\mathrm{CH}$. Muralimohan et al, "Evaluation of Microstructures and Mechanical Properties of Dissimilar Materials by Friction Welding”, Procedia Materials Science, vol.5, pp. 1107-1113, 2014.

40. C.V. Rao et al,'Microstructure and Pitting Corrosion Resistance of AA2219 Al-Cu Alloy Friction Stir Welds-Effect of Tool Profile", Defence Technology, vol.11, pp.123-131, 2015.

41. V.C.Sinha et al, "Microstructure and Mechanical Properties of Similar and Dissimilar Joints of Aluminium Alloy and Pure Copper by Friction Stir Welding.", Perspective in Science, vol. 8, pp.543-546, 2016.

42. G. Casalino et al, "FEM Analysis of Fiber Laser Welding of Titanium and Aluminum," Procedia CIRP, vol. 41, pp. 992997, 2015.

43. Y. Ai et al, "A Defect-Responsive Optimization Method for the Fiber Laser Butt Welding of Dissimilar Materials", Procedia Structural Integrity, vol.2, pp.1007-1014, 2016.

44. H-C Chen et al, "Fibre Laser Welding of Dissimilar Alloys of Ti-6 Al-4V and Inconel 718 for Aerospace Applications", International Journal Advance Manufacturing Technology, vol.52, pp.977-987, 2010.

45. V.I. Isaev et al,"Numerical Study of Heat Modes of Laser Welding of Dissimilar Metals with an Intermediate Insert”, International Journal of Heat and Mass Transfer, vol.99, pp.711-720, 2016. 